\title{
Erratum to: Turbulent velocity, sediment motion and particle trajectories under breaking tidal bores: simultaneous physical measurements
}

\author{
Nazanin Khezri · Hubert Chanson
}

Published online: 3 June 2014

C Springer Science+Business Media Dordrecht 2014

\section{Erratum to: Environ Fluid Mech DOI 10.1007/s10652-014-9358-z}

Unfortunately, in the original publication of this article the first author's last name was wrongly captured as Khzeri where it should be Khezri.

The online version of the original article can be found under doi:10.1007/s10652-014-9358-z.

N. Khezri · H. Chanson $(\varangle)$

School of Civil Engineering, The University of Queensland,

Brisbane, QLD 4072, Australia

e-mail: h.chanson@uq.edu.au

URL: http://www.uq.edu.au/ e2hchans/ 